\title{
Evaluation of constraints in bioremediation of weathered hydrocarbon-contaminated arid soils through microcosm biopile study
}

\author{
K. Ramadass ${ }^{1}$ - E. Smith ${ }^{1} \cdot$ T Palanisami $^{1}$ - G. Mathieson ${ }^{1}$ - P. Srivastava ${ }^{2}$. \\ M. Megharaj ${ }^{1,2} \cdot$ R. Naidu ${ }^{1,2}$
}

Received: 31 August 2014/Revised: 17 November 2014/Accepted: 14 March 2015/Published online: 9 April 2015

(C) Islamic Azad University (IAU) 2015

\begin{abstract}
This research investigated the factors influencing bioremediation (biopile) of arid soils contaminated by weathered hydrocarbons. Five soils were thoroughly characterised to determine total petroleum hydrocarbons (TPH), their physicochemical properties and microbial diversity. Identified biopile-limiting factors are to be elevated petroleum hydrocarbon concentrations, high electrical conductivity and the magnitude of the recalcitrant hydrocarbon fraction. To optimise the biopile parameters, microcosm study was conducted which showed significant TPH reduction in three of five soils (BP-1, BP2 and BP-4) but not in other two (BP-3 and BP-5), where BP-3 had a very high hydrocarbon concentration $\left(123,757 \mathrm{mg} \mathrm{kg}^{-1}\right)$ and BP-5 had a high proportion of recalcitrant hydrocarbons $\left(>70 \%\right.$ of $\mathrm{C}_{29}$ ). Highest TPH removal $(68 \%)$ occurred in soil BP-2 and the lowest $(5 \%)$ in soil BP-3 over 56 days. Surfactant (Triton) addition, nutrient amendment or the soil dilution did not improve TPH degradation in soils BP-3 and BP-5. Phylogenetic analysis conducted during the remediation process found that hydrocarbon concentration and hydrocarbon fraction exerted the main effect on bacterial abundance, diversity and assemblage composition. At lower concentrations $\left(\sim 1000-4000 \mathrm{mg} \mathrm{kg}^{-1}\right)$, bacterial diversity and abundance increased significantly, whilst
\end{abstract}

K. Ramadass

kavitha.ramadass@unisa.edu.au

1 Centre for Environmental Risk Assessment and Remediation, University of South Australia, Mawson Lakes, SA 5095, Australia

2 Cooperative Research Centre for Contamination Assessment and Remediation of the Environment, Mawson Lakes, SA 5095, Australia decreased in higher concentrations. Although high TPH content and detection of TPH degraders, TPH biodegradation is limited in soil (BP-5) due to the presence of less soluble hydrocarbon fraction which indicated low TPH bioavailability $(\sim 7 \%)$. Biopile could be applied as a technology to remediate three soils (BP-1, BP-2 and BP4) but further modification of the biopile treatments required for other two soils BP-3 and BP-5.

Keywords Bioremediation - Biopile - Weathered hydrocarbons $\cdot$ Microbial diversity $\cdot$ Pyrosequencing $\cdot$ TPH

\section{Introduction}

Mining and other industries operating in the resource sectors are always under constant pressure to balance productivity and environmental responsibility. Environmental accountability, social responsibility and commercial success are now incorporated into the Australian mining industry ethos. Accordingly, industries are working to reduce their environmental liability through mitigation of environmental impacts of their operations (Bernoth et al. 2000). Petroleum hydrocarbon compounds, in particular the $>\mathrm{C}_{16}-\mathrm{C}_{40}$ fractions originating from light and heavy diesels, heavy oil and other hydrocarbon products from the mining industry, contaminate both aquatic and terrestrial environments (Guerin 2002). Diesel fuel consumption in the mining industries for both on-site (mine fleet) and offsite (ore transport) is enormous, for instance, the iron ore industry in Western Australia alone consuming in excess of 3 million litres of diesel each day (Shastri et al. 2012). Inadvertent and accidental hydrocarbon contamination of soils is a common issue in various mining activities. The most common waste management practice adopted by the 
industry is landfarming and/or stockpiling much of the hydrocarbon-contaminated soils on-site, and later disposing of the material into a suitable landfill. This practice is expensive and not a sustainable solution to the problem (Hazen et al. 2003). Industry is therefore looking for the development of cost-effective and sustainable remediation practices.

Biopile is one of the cost-effective remediation techniques that may be utilised to remediate petroleum hydrocarbon-contaminated soils. Biopiles are a hybrid of landfarming and composting in which excavated soils are mixed with soil amendments, placed on a treatment area and bioremediated using forced aeration, and it can be engineered or non-engineered. The basic biopile system includes a treatment bed, an aeration system, an irrigation/nutrient system and a leachate collection system; they are a refined version of landfarming that tends to control physical losses of the contaminants by leaching and volatilisation. Biopiles provide a favourable environment for indigenous aerobic micro-organisms. USEPA (2004) defined "Biopiles, as biocells and compost piles, are used to reduce concentrations of petroleum products in excavated soils through the processes of biodegradation." Its application for hydrocarbon waste treatment, principally as ex situ engineered biopile, has been assisted to a shift towards risk-based, remedial design and technology verification. However, the development and application of this technology for arid regions are often complicated by a highly erratic rainfall, extremes of long dry periods and occasional flooding. In addition, the soils on which mining operations take place are often very infertile (CSIRO 2011). Other challenges faced in remediating these contaminated soils are the often-remote location of sites, high temperatures, and optimisation of moisture and nutrient levels, limited resources and staffing to monitor the remediation process. In addition to these challenges, bioremediation might not be successful if the mining site contains weathered compounds, because more serious difficulties are encountered due to the pollutant sequestration; the organic compounds are retained on organic and mineral components of the soil by sorption or partitioning processes (Alexander 2000). To date, there have been few studies investigating the applicability of biopile treatment for contaminated soils in arid regions with a typical low organic matter and nutrient content, and a high content of weathered hydrocarbons (Balba et al. 1998; Godoy-Faúndez et al. 2008). Biopile remediation studies conducted in the Atacama desert (Chile) concluded that the bioremediation of aged, fuel oil-contaminated desert mining soils was feasible through aerated, in-vessel composting and incorporation of sawdust into the soils (Godoy-Faúndez et al. 2008). Rhykerd et al. (1999) similarly reported that $60 \%$ of total petroleum hydrocarbon (TPH) contamination was removed from desert soils after 8 months by compost soil pile treatment in Kuwait. In their study, these authors employed a bulking agent (wood chips) and NPK fertilisers (optimised at a 100:10:1 ratio), corrected soil moisture content to- $0.1 \mathrm{MPa}$ and thereby significantly enhanced the biodegradation rate of heavily contaminated desert soils.

Biopile is a preferred remediation option because of its wide acceptance. However, it is mandatory to evaluate and select remedial options with some common procedures such as soil characterisation and treatability studies. Hence, in order to select a remediation option for the hydrocarboncontaminated soils collected from arid regions of Australia, comprehensive characterisation was performed to identify the factors limiting the efficiency of any bioremediation process. The characterisation study included the key factors for bioremediation, viz. soil physicochemical characteristics $(\mathrm{pH}$, moisture content, temperature, nutrient status and texture), microbial diversity, constituent characteristics (volatility, chemical structure, concentrations and toxicity) and local climatic conditions (temperature, wind and rainfall) (Hazen et al. 2010). Soil microcosm study with radiolabelled hexadecane at bench-scale level was conducted to optimise the environmental factors for enhancing the petroleum hydrocarbon decontamination. This study is an integration of microbial and physicochemical characterisation for the hydrocarbon-contaminated soil assessment, and it can be used to determine the feasibility of biopile to apply in the arid region soils for the remediation of petroleum hydrocarbons. This study was conducted during 2012 at Centre for Environmental Risk Assessment and Remediation (CERAR), University of South Australia, Australia.

\section{Materials and methods}

\section{Soil sampling and characterisation}

Five hydrocarbon-contaminated soils (BP-1, BP-2, BP-3, BP-4 and BP-5) were sampled from the Pilbara region of Western Australia. These soils were characterised to determine total and potentially biodegradable petroleum hydrocarbons, soil physicochemical properties and microbial community profile.

Soil $\mathrm{pH}$ and electrical conductivity (EC) were determined in a soil suspension prepared in a $1: 2.5 \mathrm{w} / \mathrm{v}$ ratio using a glass electrode. Water-holding capacity (WHC) was determined gravimetrically (Gardner and Klute 1986). Soil texture was assessed according to the method 
described by Miller and Miller (1987). Dissolved organic carbon (DOC) was analysed using a TOC analyser (O-IAnalytical, College Station, TX, USA). All soil samples were analysed for total carbon $(\mathrm{C})$ and nitrogen $(\mathrm{N})$ by dry combustion with a Trumac $\mathrm{CN}$ analyser (Leco ${ }^{\circledR}$ Corporation, Michigan, USA). The soils were also analysed for water-extractable cations and anions by preparing a soil extract 1:5 w/v ratio. Metal analysis was conducted using an ICP-MS Agilent 7500c Inductively Coupled Plasma Mass Spectrometer (ICP-MS, Agilent Technologies, Tokyo, Japan) after appropriate dilutions of the extracts. Quality control was monitored during analysis by addition of reference samples and blanks for every 20 samples analysed. Recovery of reference samples was always between 90 and $110 \%$.

\section{Total petroleum hydrocarbon (TPH) analysis}

\section{Total concentration using exhaustive extraction}

The sequential ultrasonic solvent extraction method (Risdon et al. 2008) was used to extract TPH compounds from the soil samples. Quantification of TPH concentration was carried out using a gas chromatograph fitted with a flame ionisation detector (GC-FID, Agilent 6890). Chromatography was performed on a fused-silica capillary column BPX-5 from SGE $(15 \mathrm{~m} \times 0.32 \mathrm{~mm}$ internal diameter $)$ coated with HP-5 $(0.10-\mu \mathrm{m}$ film thickness). Helium was used as the carrier gas at $2.5 \mathrm{~mL} \mathrm{~min}{ }^{-1}$, and the FID detector temperature maintained at $300{ }^{\circ} \mathrm{C}$. Splitless injection with a sample volume of $1 \mu \mathrm{L}$ was applied. The oven temperature was increased from 50 to $300{ }^{\circ} \mathrm{C}$ at a gradient of $25{ }^{\circ} \mathrm{C} \mathrm{min}{ }^{-1}$ and held at this temperature for $5 \mathrm{~min}$. The total run time was $19.6 \mathrm{~min}$.

Hydrocarbons were quantified using Agilent ChemStation Software by integration and calibration of peaks of a known concentration of an external calibration standardHydrocarbon Window Defining Standard $\left(\mathrm{C}_{8}-\mathrm{C}_{40}\right)$ from AccuStandard ${ }^{\circledR}$ (Risdon et al. 2008). Five concentrations of external calibration standard in the range expected in the samples were analysed; a linear curve fit with a $R^{2}$ value of 0.997 was obtained. The continuing calibration verification (CCV) was analysed at the start and end of every 20 samples, and CCV recovery was $95-110 \%$ of true value. Hexane was run as blank with every ten samples to demonstrate that the system was free from contamination. The surrogate (o-terphenyl) was spiked at a level to produce a recommended extract concentration of $20 \mu \mathrm{g} \mathrm{mL}^{-1}$. Surrogate recoveries lay in the range $70-120 \%$ for all the samples analysed. The minimum concentration of TPH detected (MDL) through this analytical method was $35 \mathrm{mg} \mathrm{kg}^{-1}$.

\section{Bioavailable concentrations using mild extraction}

A mild soil extraction technique for estimating bioavailable fractions of the hydrocarbons using aqueous HP- $\beta$ CD (2-hydroxypropyl- $\beta$-cyclodextrin) was adapted from the method described by Reid et al. (2000). Dried and sieved soil samples $(5 \mathrm{~g}, n=3)$ were taken, and $100 \mathrm{~mL}$ of $50 \mathrm{~mm}$ aqueous solution of HP- $\beta-C D$ was added. The soil + HP- $\beta-C D$ solution was then placed on an orbital shaker (Fisher Scientific, Australia) set at $100 \mathrm{rpm}$ for $20 \mathrm{~h}$ prior to centrifugation at $27,000 \mathrm{~g}$ for $30 \mathrm{~min}$ (Beckman ja21/2 centrifuge, USA). The soil residues were separated from the supernatant after centrifugation and dried at $37^{\circ} \mathrm{C}$ for estimating the non-desorbing or the presumed non-bioavailable fraction by exhaustive extraction. This extraction was considered as a prescreening chemical assay to predict the hydrocarbon degradation endpoint.

DNA extraction, amplification of $16 \mathrm{~S}$ rRNA genes and pyrosequencing

The total microbial community DNA was isolated from $1 \mathrm{~g}$ of soil for each sample. A MoBio soil DNA extraction kit (MoBio Laboratories, Carlsbad, CA) was used according to the manufacturer's instruction. Amplification of 16S rRNA genes and pyrosequencing of all the extracted soil DNA were performed at the Australian Genomic Research Centre (AGRF), Brisbane, Australia. PCR amplicons were generated using the primers and conditions outlined in Table 1 using AmpliTaq Gold 360 Mastermix (Life Technologies, Australia). The resulting amplicons were measured by fluorometry, normalised, measured by qPCR, normalised a second time and then pooled in equimolar ratios. This amplicon pool was then run on the GS FLX platform using XLR70 chemistry (Roche, Australia). It has been reported that Roche 454 GS FLX pyrosequencing can provide 1 million sequence reads of 500 million base pairs of sequence information in a single run at relatively low cost (Voelkerding et al. 2009). This strategy has been adopted for environmental microbial diversity investigation, and therefore, pyrosequencing in our investigation was followed to assess the microbial abundance and diversity in soils contaminated with the hydrocarbons for a long period of time.

\section{Microcosm biopile treatment}

A microcosm study was conducted to establish the optimal conditions for effective biopile treatment of the petroleum hydrocarbon-contaminated soils at bench scale. This included a range of different treatments designed to enhance 
Table 1 Primers and conditions for 454 pyrosequencing

\begin{tabular}{|c|c|c|c|c|}
\hline $\begin{array}{l}\text { Amplicon } \\
\text { name }\end{array}$ & Target & Forward sequence & Reverse sequence & PCR conditions \\
\hline $\begin{array}{l}16 \mathrm{~S} 27 \mathrm{~F}- \\
519 \mathrm{R}\end{array}$ & Bacteria & $\begin{array}{l}\text { AdptB_27F_U- } \\
\text { AGAGTTTGATCMTGGCTCAG }\end{array}$ & $\begin{array}{l}\text { AdptA_519R_1- } \\
\text { GWATTACCGCGGCKGCTG }\end{array}$ & $\begin{array}{l}94{ }^{\circ} \mathrm{C} \text { for } 3 \mathrm{~min} ; 34 \times\left(94{ }^{\circ} \mathrm{C} \text { for } 45 \mathrm{~s},\right. \\
\left.50{ }^{\circ} \mathrm{C} \text { for } 60 \mathrm{~s}, 72{ }^{\circ} \mathrm{C} \text { for } 60 \mathrm{~s}\right) ; 72{ }^{\circ} \mathrm{C} \\
\text { for } 7 \mathrm{~min}\end{array}$ \\
\hline $\begin{array}{l}16 \mathrm{~S} 341 \mathrm{~F}- \\
806 \mathrm{R}\end{array}$ & Bacteria & $\begin{array}{l}\text { AdptA_341F_U- } \\
\text { CCTAYGGGRBGCASCAG }\end{array}$ & $\begin{array}{l}\text { AdptB_806R_U- } \\
\text { GGACTACNNGGGTATCTAAT }\end{array}$ & $\begin{array}{l}98{ }^{\circ} \mathrm{C} \text { for } 30 \mathrm{~s} \text {, followed by } 35 \text { cycles at } \\
98^{\circ} \mathrm{C} \text { for } 5 \mathrm{~s}, 56{ }^{\circ} \mathrm{C} \text { for } 20 \mathrm{~s} \text { and } \\
72{ }^{\circ} \mathrm{C} \text { for } 20 \mathrm{~s} \text { and a final extension } \\
\text { time of } 72{ }^{\circ} \mathrm{C} \text { for } 5 \mathrm{~min}\end{array}$ \\
\hline $\begin{array}{l}\text { ITS } 1 \mathrm{~F}- \\
\quad 4 \mathrm{R}\end{array}$ & Fungi & $\begin{array}{l}\text { AdptA_ITS1F_1- } \\
\text { CTTGGTCATTTAGAGGAAGTAA }\end{array}$ & $\begin{array}{l}\text { AdptB_ITS4R_U- } \\
\text { TCCTCCGCTTATTGATATGC }\end{array}$ & $\begin{array}{l}94{ }^{\circ} \mathrm{C} \text { for } 3 \mathrm{~min} ; 30 \times\left(95^{\circ} \mathrm{C} \text { for } 30 \mathrm{~s} \text {, }\right. \\
\left.55^{\circ} \mathrm{C} \text { for } 30 \mathrm{~s}, 72{ }^{\circ} \mathrm{C} \text { for } 60 \mathrm{~s}\right) ; 72^{\circ} \mathrm{C} \\
\text { for } 2 \mathrm{~min}\end{array}$ \\
\hline
\end{tabular}

the bioremediation of petroleum hydrocarbon-contaminated soils from the Pilbara region. In addition, it utilised radiolabelled hexadecane for assessing the efficacy of the treatment options.

\section{${ }^{14} \mathrm{C}$-hexadecane mineralisation assay}

Soil microcosms were prepared in $500 \mathrm{~mL}$ respirometer bottles with caps lined with PTFE. $10 \mathrm{Kbq}$ of hexadecane ${ }^{14} \mathrm{C}$ (Sigma-Aldrich Australia), dissolved in $4.3 \mathrm{~mL}$ of dimethylsulfoxide (DMSO), was added to each bottle. $150 \mathrm{~g}$ of soil was then added and the bottle rolled and shaken gently to mix the soil and labelled hexadecane. Treatment components for each test of the microcosm are T1-Sand control; T2-100 \% BP-1; T3-100\% BP-2; T4-100 \% BP-3; T5-50\% BP-3 + 50\% Sand; T6$50 \%$ BP-3 + $50 \%$ BP-1; T7-100\% BP-4; T8-40\% BP-4 + $60 \%$ Sand; T9-50\% BP-4 + 50\% BP-1; $\mathrm{T} 10-100 \%$ BP-5; $\mathrm{T} 11-50 \%$ BP-5 + $50 \% \quad \mathrm{BP}-1$; $\mathrm{T} 12-25 \% \quad \mathrm{BP}-5+75 \% \quad \mathrm{BP}-1 ; \quad \mathrm{T} 13-100 \% \mathrm{BP}-$ $5+2 \%$ Triton. The soil $\mathrm{C}: \mathrm{N}: \mathrm{P}$ ratios of all the soils were adjusted to 100:10:1, and the WHC maintained at 50-60\% using an aqueous solution containing $\mathrm{N}$ (ammonium nitrate) and $\mathrm{P}$ (potassium dihydrogen phosphate) salts. A glass vial $(22 \mathrm{~mL})$ containing $2 \mathrm{~mL}$ of $1 \mathrm{M} \mathrm{NaOH}$ was placed inside the bottle to trap evolved $\mathrm{CO}_{2}$. The microcosm bottles were then sealed with screw caps and incubated at $22{ }^{\circ} \mathrm{C}$, unless otherwise specified. The $\mathrm{NaOH}$ solution in the glass vials was replaced weekly. The glass vial solution was mixed with $10 \mathrm{~mL}$ of Beckman Ready Gel scintillation cocktail, and the trapped ${ }^{14} \mathrm{CO}_{2}$ determined in a Beckman LS6000IC counter.

\section{Statistical analysis}

All treatments were triplicated, and the data shown are the means of the treatments. Where mentioned, significant differences between treatments were determined using Tukey's post hoc test $(p<0.05)$ (Beolchini et al. 2010). A correlation coefficient matrix was constructed using Pearson's product-moment correlation to test for any significant correlations between the soil characteristics. All statistical analyses were carried out using SPSS statistics software version 20 .

\section{Results and discussion}

\section{Bioavailability of weathered hydrocarbons}

Limited bioavailability of hydrocarbons in a terrestrial environment due to low water solubility or interactions with the soil matrix often corresponds to inhibition of the degradation rate. Therefore, while characterising a contaminated soil for its suitability for biopile technique, it is important to estimate the fraction of TPH that is potentially biodegradable/bioavailable. Measuring only the overall TPH concentration in a soil gives little insight into the fraction of the TPH which is potentially biodegradable. There is much evidence to suggest that the current regulatory procedures overestimate the truly biodegradable fraction (Harmsen and Naidu 2013). Thus, a methodology that predicts the 'bioavailable fraction' would be useful for presuming 'actual' exposure limits and provides a more relevant basis for risk assessment would serve as a preliminary site investigation tool (Naidu et al. 2013). Here in this study, HP- $\beta$-CD (2-hydroxypropyl- $\beta$-cyclodextrin) extraction was considered to estimate the potentially degradable fraction of TPH as it is the most commonly adopted chemical assay for measurement of the bioavailable hydrophobic organic contaminants (Riding et al. 2013).

HP- $\beta-C D$ extractions in the five soils suggest that bioavailable fraction ranged from $7.3 \%$ (BP-5) to $62.6 \%$ (BP-12) (Fig. 1). The assay highlighted that not all the TPH fractions may be potentially available for the bioremediation, and a residual TPH component will always remain in the soil. The bioavailability-screening assay, in 
conjunction with the TPH concentrations, indicated that a satisfactory bioremediation endpoint might not be achieved in soils BP-3 and BP-5. Soil BP-3 appeared difficult to remediate as the TPH concentration was highly elevated, exceeding $100,000 \mathrm{mg} \mathrm{kg}^{-1}$. It is generally accepted that soils with TPH concentrations $>50,000 \mathrm{mg} \mathrm{kg}^{-1}$ are difficult to be bioremediated (Admon et al. 2001; USEPA 2004). Huesemann et al. (2002) reported that for effective bioremediation, the optimal petroleum hydrocarbon concentration in soils ranges from 0.2 to $5.5 \%$ by volume of oil. TPH concentration in BP-5 was $27,827 \mathrm{mg} \mathrm{kg}^{-1}$ which is well within this optimal range. However, further investigation of the distribution of TPH fractions in the soil indicated that it mostly $(>70 \%)$ contained hydrocarbons in the $>\mathrm{C}_{28}-\mathrm{C}_{40}$ range and only about $2000 \mathrm{mg} \mathrm{kg}^{-1} \mathrm{TPH}$ was HP- $\beta$-CD-extractable. The apparent low solubility and sequestration of hydrocarbons due to ageing/weathering may be factors behind the decline in bioavailability for soil BP-5 (Brassington et al. 2007). Quantification of both total and biodegradable concentrations of TPH in the contaminated soils revealed that some soils might be suitable for bioremediation (BP-1, BP-2, BP-4), whilst others are

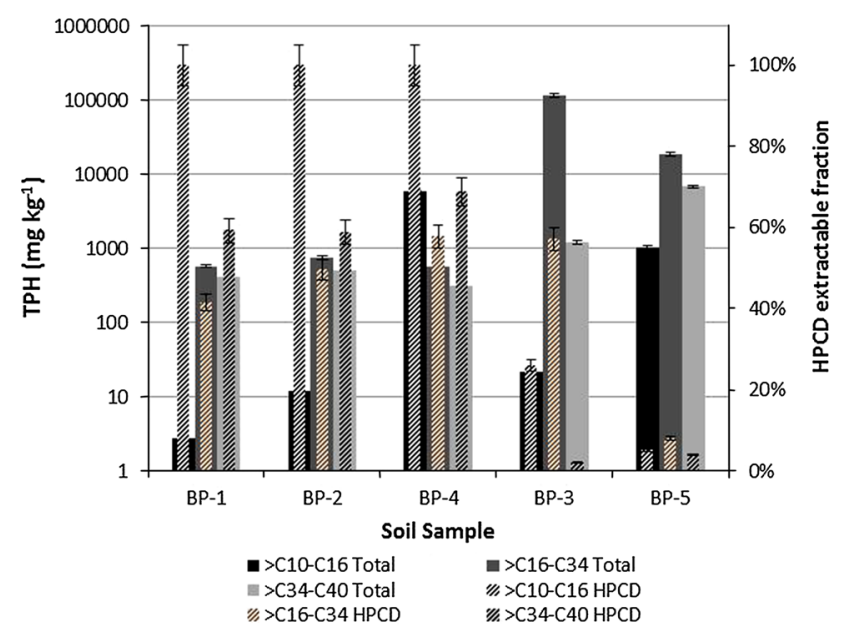

Fig. 1 Total and potentially biodegradable petroleum hydrocarbons in arid soils. Error bar represents standard error $(n=3)$ not (BP-3 and BP-5). Soil is a complex matrix, and it is essential to consider several parameters other than the pollutant concentrations in the investigation of designing site remediation (Masakorala et al. 2013). Therefore, correlation analysis between physicochemical and biological parameters of soil and TPH concentrations was performed. The interdependences between the soil physicochemical parameters analysed including TPH, and biological characteristics are shown in the Table 3.

\section{Defining other soil parameters than TPH and their interrelationship to design biopile}

Several studies have highlighted that factors such as soil organic matter (SOM) content, temperature, $\mathrm{pH}$, salinity, nutrient availability (particularly nitrogen and phosphorus), soil moisture content, oxygen availability and redox potential affect the bioremediation processes (Chaillan et al. 2006; Ehlers and Luthy 2003; Semple et al. 2003, 2004). Since these factors decide the outcome of the bioremediation, in this study, soils were characterised accordingly (Table 2). Soil pH ranged from 7.26 to 8.51 and the EC from 181 to $2210 \mu \mathrm{S} \mathrm{cm}^{-1}$, with a markedly higher value for BP-4. The level of organic matter was low, and TPH was the major carbon source in these soils. In addition to low soil carbon, these soils contained low concentrations of major nutrients required for microbial growth. Optimal molar nutrient ratios were not found in all the soils $[\mathrm{C}: \mathrm{N}$ ratio 56:1 (BP-4) to 403:1 (BP-2)]. Factor analysis was done with PCA extraction and correlation analysis to study the relationship among different physicochemical parameters including TPH and biological parameters. The intercorrelations among the parameters are shown in the correlation matrix (Table 3) and the score plot (Fig. 2). The score plot of principal component analysis is presented in Fig. 2, and the nature of relationships among studied parameters is readily seen. On the first component, heavy positive loading marked by TPH both total (0.939) and bioavailable (0.859) concentration, TPH fractions F2 $\left(>\mathrm{C}_{10}-\mathrm{C}_{16}\right)(0.952)$ and $\mathrm{F} 3\left(>\mathrm{C}_{16}-\mathrm{C}_{34}\right)(0.915)$, Carbon (0.980), Nitrogen (0.925) and WHC (0.816), while heavy

Table 2 Physicochemical properties of weathered hydrocarbon-contaminated soils

\begin{tabular}{llllllllrl}
\hline $\begin{array}{l}\text { Soil } \\
\text { code }\end{array}$ & $\begin{array}{l}\text { Bulk density } \\
\left(\mathrm{g} \mathrm{cm}^{-3 \mathrm{z}}\right)\end{array}$ & $\begin{array}{l}\text { Porosity } \\
(\%)\end{array}$ & $\begin{array}{l}\text { Water-holding } \\
\text { capacity }(\%)\end{array}$ & $\begin{array}{l}\text { Drainage } \\
\left(\mathrm{mL} \mathrm{min}{ }^{-1}\right)\end{array}$ & $\begin{array}{l}\mathrm{pH}(1: 2.5 \\
\left.\mathrm{H}_{2} \mathrm{O}\right)\end{array}$ & \multicolumn{1}{l}{$\begin{array}{l}\mathrm{EC} \\
\left(\mu \mathrm{S} \mathrm{cm}^{-1}\right)\end{array}$} & Carbon $(\%)$ & Nitrogen $(\%)$ & $\mathrm{C}^{\mathrm{a}}$ \\
\hline $\mathrm{BP}-1$ & $2.04 \pm 0.01$ & $26.8 \pm 1.1$ & $21.2 \pm 1.2$ & $240 \pm 12.2$ & $8.31 \pm 0.05$ & $478 \pm 18.4$ & $0.64 \pm 0.03$ & $0.012 \pm 0.001$ & $62 \pm 0.8$ \\
$\mathrm{BP}-2$ & $2.16 \pm 0.03$ & $25.5 \pm 1.5$ & $19.3 \pm 2.3$ & $70.6 \pm 2.0$ & $8.51 \pm 0.07$ & $594 \pm 15.6$ & $0.69 \pm 0.01$ & $0.002 \pm 0.002$ & $403 \pm 1.2$ \\
$\mathrm{BP}-3$ & $1.57 \pm 0.01$ & $27.8 \pm 1.8$ & $34.0 \pm 2.1$ & $38.7 \pm 1.2$ & $7.69 \pm 0.05$ & $181 \pm 5.6$ & $9.45 \pm 0.09$ & $0.036 \pm 0.001$ & $306 \pm 2.5$ \\
$\mathrm{BP}-4$ & $1.04 \pm 0.01$ & $56.4 \pm 2.2$ & $28.4 \pm 2.0$ & $12.0 \pm 0.88$ & $7.63 \pm 0.06$ & $2210 \pm 20.6$ & $0.53 \pm 0.02$ & $0.011 \pm 0.001$ & $56 \pm 1.4$ \\
$\mathrm{BP}-5$ & $1.54 \pm 0.01$ & $31.8 \pm 1.9$ & $27.2 \pm 2.1$ & $300 \pm 15.2$ & $7.26 \pm 0.06$ & $655 \pm 12.6$ & $7.64 \pm 0.06$ & $0.035 \pm 0.002$ & $255 \pm 1.3$ \\
\hline
\end{tabular}

${ }^{a}$ Molar nutrient ratio. Values are mean $(n=3)$ with standard error 


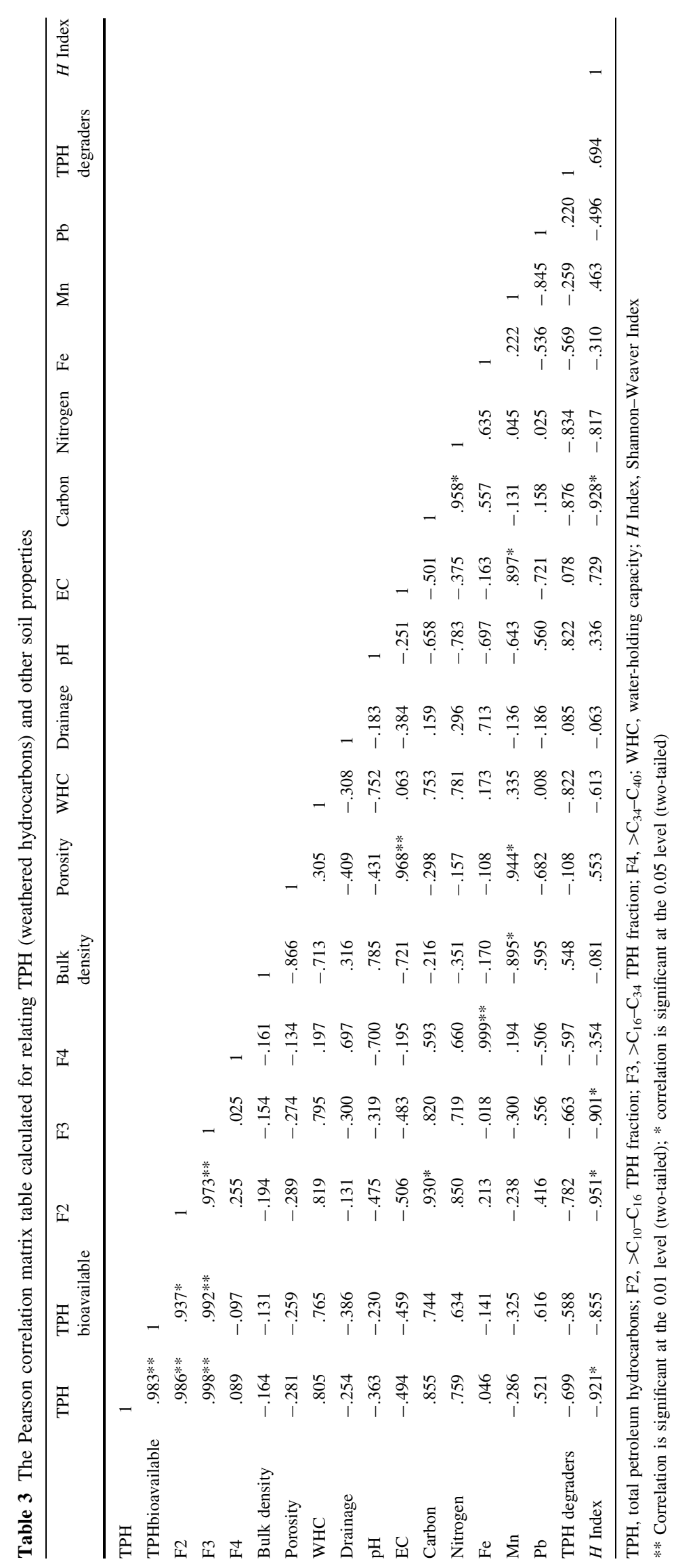


negative loading resulted by hydrocarbon degraders count, and $H^{\prime}$ Index. Compared to the loadings on component two, considerably high negative loadings were resulted by bulk density and $\mathrm{pH}$. Correlation values $\left(r^{2}\right)$ of TPH concentrations with soil carbon concentration, TPH degraders, bacterial species diversity $\left(H^{\prime}\right.$ Index $)$ and soil water-

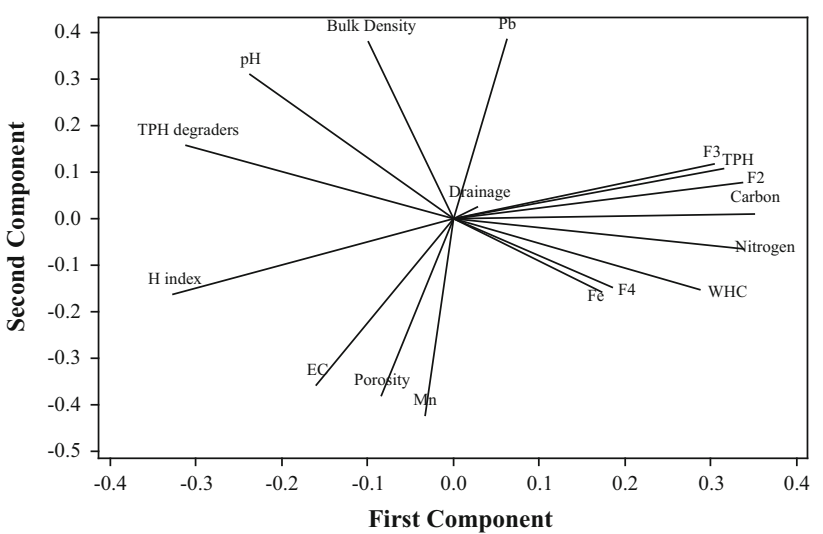

Fig. 2 Score plot, based on principal component analysis, showing relationship between TPH and other soil parameters $\left(\mathrm{F} 2-\mathrm{C}_{10}-\mathrm{C}_{16}\right.$; $\mathrm{F} 3 \longrightarrow \mathrm{C}_{16}-\mathrm{C}_{34} ;>\mathrm{C}_{34}-\mathrm{C}_{40}$ ) holding capacity were $0.855 \quad(p<0.05), \quad-0.699$ $(p<0.05),-0.921(p<0.05)$ and $0.805(p<0.05)$, respectively. It is interesting to note that the calculated correlation coefficients was highly significant for the parameters like TPH concentration both total and bioavailable, hydrocarbon fractions $\mathrm{F} 2\left(>\mathrm{C}_{10}-\mathrm{C}_{16}\right)$ and $\mathrm{F} 3$ $\left(>\mathrm{C}_{16}-\mathrm{C}_{34}\right)$, carbon, nitrogen and the WHC. These parameters were closely associated with each other showed their interdependence while the other remaining parameters such as $\mathrm{pH}, \mathrm{EC}$, bulk density, porosity, metals $(\mathrm{Pb}$ and $\mathrm{Mn}$ ), hydrocarbon degrader's count and $H^{\prime}$ Index showed clear separation from the TPH concentration. EC and porosity values of the soils characterised showed high correlation $\left(r^{2}=0.961 p<0.01\right)$, which explained the fact that the soil porosity is one of the factors affecting the apparent electrical conductivity of the soil (Friedman 2005). The microbiological parameters revealed a strong negative correlation with the TPH, and this explained that the diversity is more for the less contaminated soils. Masakorala et al. (2013) also found a clear separation of cultivable bacteria population size (CBPS) from the soil parameters such as TPH, soil enzymes and groundwater
Fig. 3 Bacterial dynamicsphylogenetic classification in the weathered hydrocarboncontaminated soils
BP1

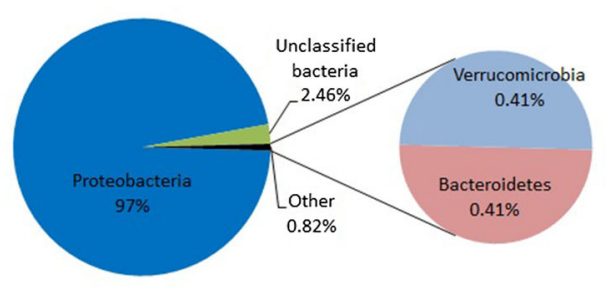

BP3
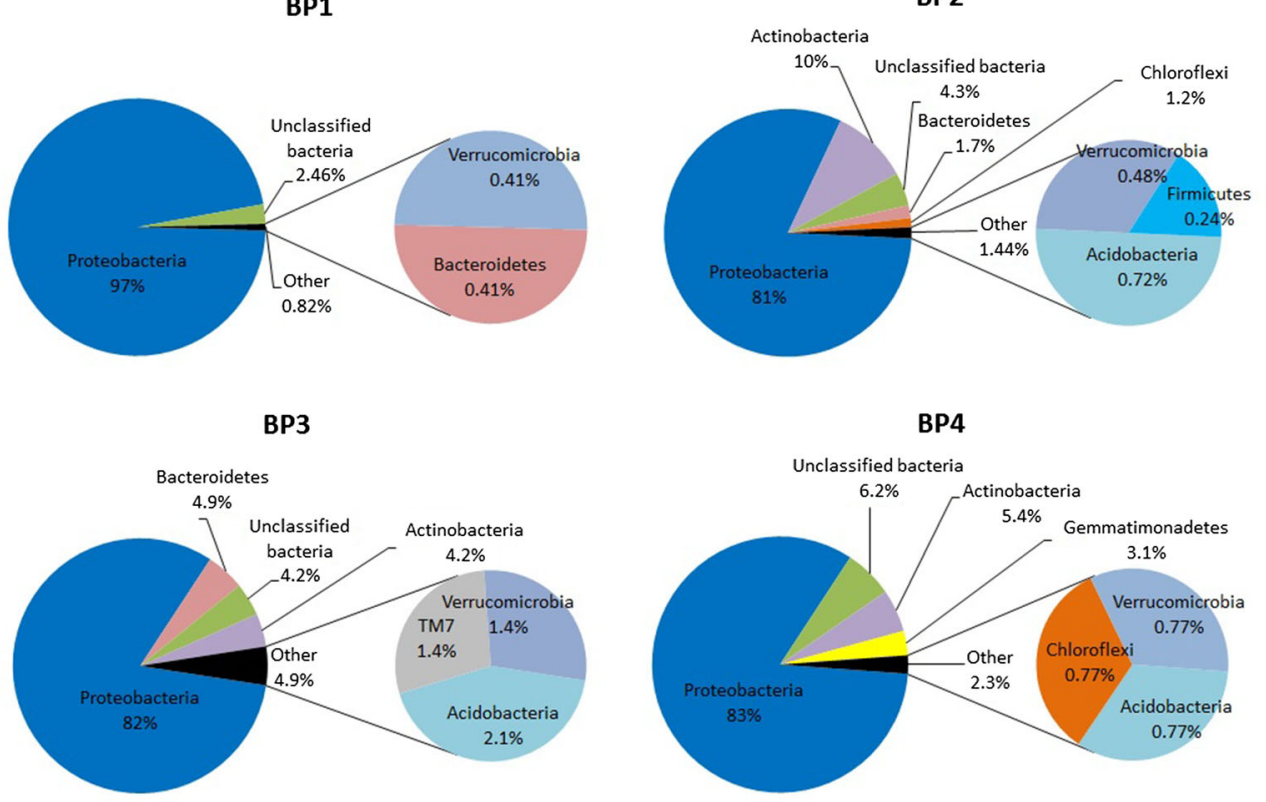

BP5

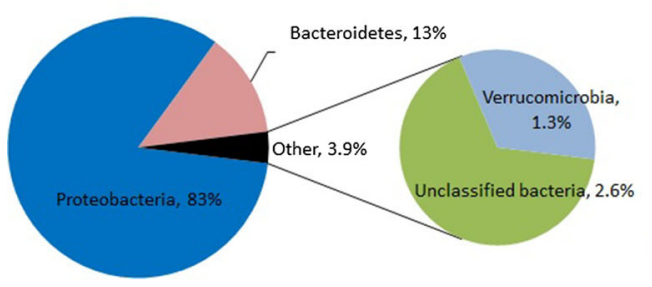


potential. Microbial dynamics are strongly accountable for the bioremediation of any contaminated environment including oil-contaminated soils, which is discussed in more detail in the next section.

\section{Dynamics of hydrocarbon-degrading microbes in the contaminated soils}

Biodegradation potential is governed by the intrinsic physicochemical properties of soils as well as ambient moisture conditions, temperature, and the presence of a microbial community capable of degrading petroleum hydrocarbons (Gargouri et al. 2013). Contaminants exert selective forces on the microbial community resulting in a shift in their dynamics (Griebler and Lueders 2009) either due to direct toxic effects or to competition. Effective bioremediation of TPH-contaminated soils is dependent on the presence of indigenous micro-organisms that are capable of degrading hydrocarbon compounds. An investigation of the diversity of native micro-organisms is a key step in understanding microbial remediation of the hydrocarbon-contaminated soils. For microbial diversity profiling, culture-based techniques are limited because only about $1 \%$ of microbes are able to be routinely cultured under laboratory conditions (Zhang and Xu 2008). This makes it very difficult to link any contaminant transformation to phylogenetic identity of active microbes and has therefore become a main challenge in bioremediation studies. The recent development of new molecular techniques has made it possible to link structure and function of active communities. High-throughput sequencing methods such as 454 pyrosequencing can be used to provide detailed information on the taxonomy and metabolic potential of microbial communities in contaminated environments (Mason et al. 2012; Yergeau et al. 2012).

Pyrosequencing grouped the sequences obtained from the present soil samples into 13 different bacteria phyla (Fig. 3). BP-3, BP-2 and BP-4 contained more bacterial phylotypes consisting of Proteobacteria (mainly Gammaproteobacteria and Alphaproteobacteria), Actinobacteria, Acidobacteria, Bacteroidetes and Chloroflexi. Verrumicrobia and TM7 were found as minor communities. Prince (2010) reported that a broad range of bacterial phylogenetic groups, comprising at least 150 genera, had been identified as hydrocarbon-degrading bacteria. The majority belong to the Proteobacteria, but representatives of the Firmicutes, Actinobacteria, Bacteroidetes and Chloroflexi are also frequently encountered. The pyrosequencing results (Fig. 3) were similar to those reported by Prince (2010), and Actinobacteria was the next dominant phylum present except in soil BP-5 in which bacterial diversity was relatively less than the other soils. Phylum Proteobacteria is prevalent in both polluted and unpolluted environments. 16S RNA-based pyrosequencing data have shown that the diversity of Proteobacteria and Actinobacteria may increase in hydrocarbon-contaminated soils. Several members of the Proteobacteria and Actinobacteria have been demonstrated to be involved in hydrocarbon degradation (Adetutu et al. 2013). The Proteobacteria are subdivided into three classes: Alpha-, Beta- and Gammaproteobacteria, and their ability to utilise both aliphatic and aromatic compounds has already been established (Greer et al. 2010). Zhang et al. (2012) characterised the bacterial diversity in soils contaminated by a leakage of heavy oil hydrocarbons and reported the dominance of Proteobacteria, and also found the presence of Actinobacteria. Members of Actinobacteria classification are typically gram-positive soil bacteria, which are considered to be $K$-strategists and so tend to be more successful in resource-limited situations (Atlas and Bartha 1998). Saul et al (2005) demonstrated that members of this class, typically gram-positive soil bacteria, are able to survive dry conditions. Actinobacteria are most regularly reported from extreme environments such as hot springs, deserts and other arid climates, mining operations (Bull 2011). The soils used in this research were collected from mining sites in arid regions and hence showed the presence of Actinobacteria. Members of the Bacteroidetes, the other phylum present in the soils studied, are also considered to be effective degraders of macromolecules, including cellulose and chitin (Manz et al. 1996). Bacterial classification studies by other workers have generally confirmed that Proteobacteria, Actinobacteria and Bacteroidetes are found in soils impacted by hydrocarbons (Beazley et al. 2012; Bell et al. 2011; Liu and Liu 2013; Røberg et al. 2011; Sutton et al. 2013).

The changes in bacterial communities after hydrocarbon contamination in any ecosystem have been described already (Beazley et al. 2012; Bell et al. 2011; Liu and Liu 2013). Compared to bacteria, little information exists on the dynamics of fungi following hydrocarbon contamination. Bioremediation is consistently viewed as remediation by bacteria with much less focus on mycoremediation (fungal bioremediation). Fungi are part of the soil biota that can utilise pollutants as growth substrates through low-specificity catabolic enzymes by forming extended mycelial networks. Though fungi are endowed with a capacity to degrade environmental organic chemicals, it has not been exploited for the bioremediation. By realising the greater potential of fungi by virtue of their aggressive growth, greater biomass production and extensive hyphal reach in soil, phylogenetic analysis has been undertaken in fungal communities also to identify its presence in the hydrocarbon-contaminated soil ecosystem, and to determine what role they play in hydrocarbon bioremediation. Fungal diversity analyses performed on fungal $18 \mathrm{~S}$ rRNA gene 
Fig. 4 Fungal dynamics in the weathered hydrocarboncontaminated soils. a Fungal phylotypes present in the hydrocarbon-contaminated soils. b Fungal families present in the hydrocarboncontaminated soils a

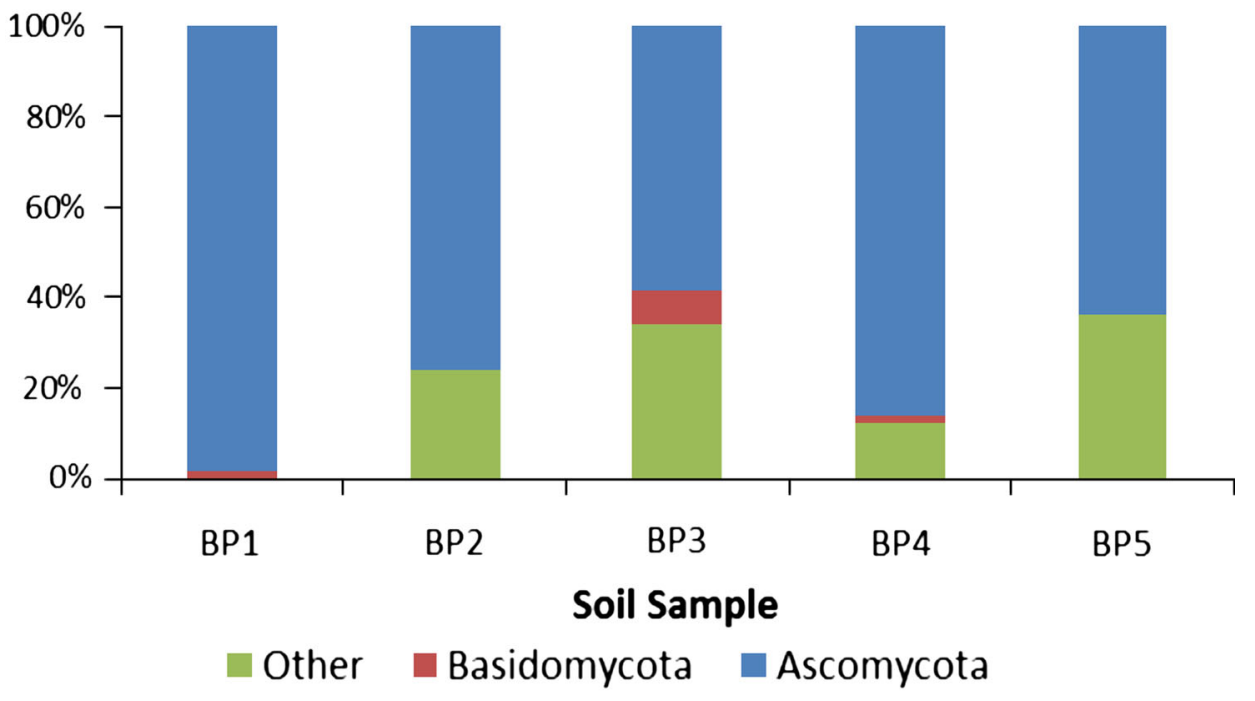

b

BP1

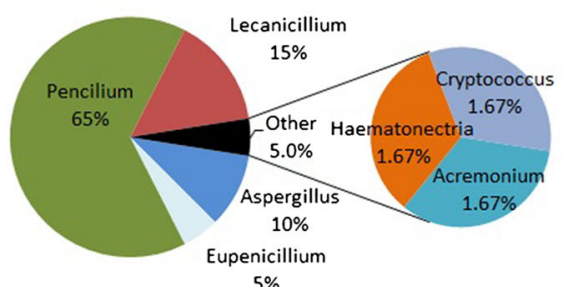

BP3
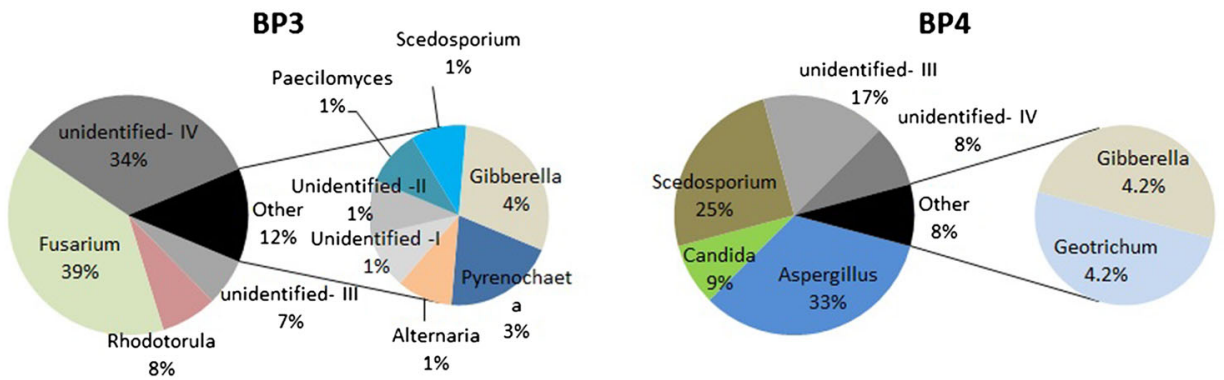

sequences were analogous to bacterial diversity analysis with $16 \mathrm{~S}$ rRNA gene sequences (Fig. 4a, b). The data revealed that Ascomycota is the predominant phylum (58-98\%) found in all the soils characterised except BP-5, where Ascomycota comprised only $12.5 \%$ of the phylum present. Ros et al. (2010) reported that Ascomycota were also the most predominant fungal division found in the soils contaminated with aged hydrocarbon pollutants. A small proportion (2-8\%) of Basidiomycota was found in soils BP-1 and BP-3. Some of the known hydrocarbon-degrading 
fungi, viz. species of Aspergillus, Acremonium, Candida, Cryptococcus, Eupenicillium, Geotrichum, Penicillium and Scedosporium, were found in soils BP-1, BP-2 and BP-4. Soil BP-3, which had an elevated hydrocarbon concentration, showed higher fungal diversity than other soils. Rhodotorula, Fusarium and Alternaria were the hydrocarbon-degrading fungi present in this soil. Less fungal diversity noticed in soil BP-5; only two fungal genera were present, and the genus which inhabited this soil mostly is as yet unidentified. Other studies (Cerniglia and Sutherland 2010; Prince 2010) have also found hydrocarbon-degrading fungi similar to the groups reported in this study.

The soils used in the study had been contaminated with petroleum hydrocarbons for more than a decade. Pyrosequencing showed that some phyla which are known TPH degraders were greater in the soils sequenced. Stenuit et al. (2008) mentioned that pyrosequencing provides direct access to environmental microbes independently of their culturability, and this study provides further evidence for the advantage of using pyrosequencing to assess the potential microbial capacity in bioremediation. This sequencing method can help in the design of suitable bioremediation methods for efficient contaminant removal or reduction. However, the detection of potential hydrocarbon-degrading microbes does not guarantee hydrocarbon removal from soils. Other environmental factors such as soil aeration, water content, nutrients and contaminant bioavailability all influence the hydrocarbon-degrading activities of soil micro-organisms (Masakorala et al. 2013). Hydrocarbon degradation with the heterotrophic bacteria and fungi can be enhanced through nutrient amendment, and this has become a common and economically viable bioremediation practice (Nikolopoulou and Kalogerakis 2009; Rocchetti et al. 2011; Teng et al. 2010). Several factors can influence the amount of $\mathrm{N}$ and $\mathrm{P}$ to be added to hydrocarbon-impacted soils, including indexation against the levels of C present in contaminated soils (Riser 1998).

Optimal nutrient dosages, however, vary with soil properties and environmental conditions, and the concentration and nature of the hydrocarbon pollutants (Walworth et al. 1997). Along with nutrient availability, soil water content also plays a major role in the hydrocarbon biodegradation rates. Water is essential for microbial growth and mobility and the diffusion of oxygen, nutrients and by-products and can be particularly important in biodegradation of organic material in soils from warm climates where temperature is limiting. Adequate soil moisture maintenance also prevents nutrients becoming toxic to soil micro-biota due to the increase in osmotic potential as the soil dries (Walworth et al. 1997). Biodegradation is generally enhanced when the WHC is between 20 and $80 \%$, although optimal values do vary with soil texture and type (Tibbett et al. 2011).

\section{Mineralisation study to optimise parameters for effective biopile treatment}

Soil characterisation only cannot accurately predict bioremediation effectiveness, and therefore, treatability tests are a prerequisite before selecting any remediation technique. Treatability studies are mainly conducted to assess the feasibility of bioremediation by estimating biodegradation rates and residual contaminant levels and determining limiting environmental conditions (e.g. electron acceptor, moisture content, nutrient content, $\mathrm{pH}$, contaminant bioavailability and temperature) to establish optimal treatment options (Sanscartier et al. 2009). Microcosm studies are widely used in treatability test procedures and generally consist of testing small volumes of the contaminated soil $(3-200 \mathrm{~g})$ in the laboratory. Soil was amended with various treatments and incubated for a specified period. Soil respiration is the common parameter used for monitoring in microcosm studies as it can be more easily measured than the hydrocarbon concentrations in the soil. Several techniques for measuring respiration are available, and one often employed is monitoring the production of ${ }^{14} \mathrm{C}$-labelled carbon dioxide $\left({ }^{14} \mathrm{CO}_{2}\right)$ from the mineralisation of an added ${ }^{14} \mathrm{C}$-labelled surrogate (Ferguson et al. 2003).

Hexadecane $\left(\mathrm{C}_{16} \mathrm{H}_{34}\right)$ is often used as a surrogate compound in mineralisation studies to assess biodegradation rates in hydrocarbon-contaminated soils. Hexadecane has a straight-chain structure and is of low aqueous solubility; it is considered to be readily biodegradable. It is representative of the aliphatic hydrocarbons present in crude oil and has been chosen by many researchers as a model contaminant (Bouchez Naïtali et al. 1999; Hua et al. 2007; Noordman et al. 2002; Stroud et al. 2008; VolkeSepúlveda et al. 2003; Wu and Ju 1998). In this study, radiolabelled hexadecane was added to the soil microcosm and the mineralisation of this compound was monitored through the evolution of ${ }^{14} \mathrm{CO}_{2}$ over a 56-day period. ${ }^{14} \mathrm{C}_{16} \mathrm{H}_{34}$ mineralisation varied considerably in all the soils studied and ranged from 5 to $68 \%$ of the added ${ }^{14} \mathrm{C}_{16} \mathrm{H}_{34}$ (Fig. 5). Abiotic hexadecane degradation was negligible, which indicated that the reduction of the hydrocarbon was mainly caused by biological degradation. The highest rates of ${ }^{14} \mathrm{C}_{16} \mathrm{H}_{34}$ mineralisation were observed in soils with low TPH concentrations where ${ }^{14} \mathrm{C}_{16} \mathrm{H}_{34}$ mineralisation ranged between 40 and $55 \%$ of the added ${ }^{14} \mathrm{C}_{16} \mathrm{H}_{34}$. Very low mineralisation occurred in soil BP-3, where ${ }^{14} \mathrm{C}_{16} \mathrm{H}_{34}$ mineralisation was only $5 \%$ of the ${ }^{14} \mathrm{C}_{16} \mathrm{H}_{34}$ added over the period of the study. The \% TPH degraded during the bioremediation was compared against the predicted degree of TPH degradation estimated through the prescreening chemical assay with HP- $\beta$-CD extraction. All soils except BP-3 showed moderate correlation $\left(R^{2}=0.64, p=0.045\right)$ 


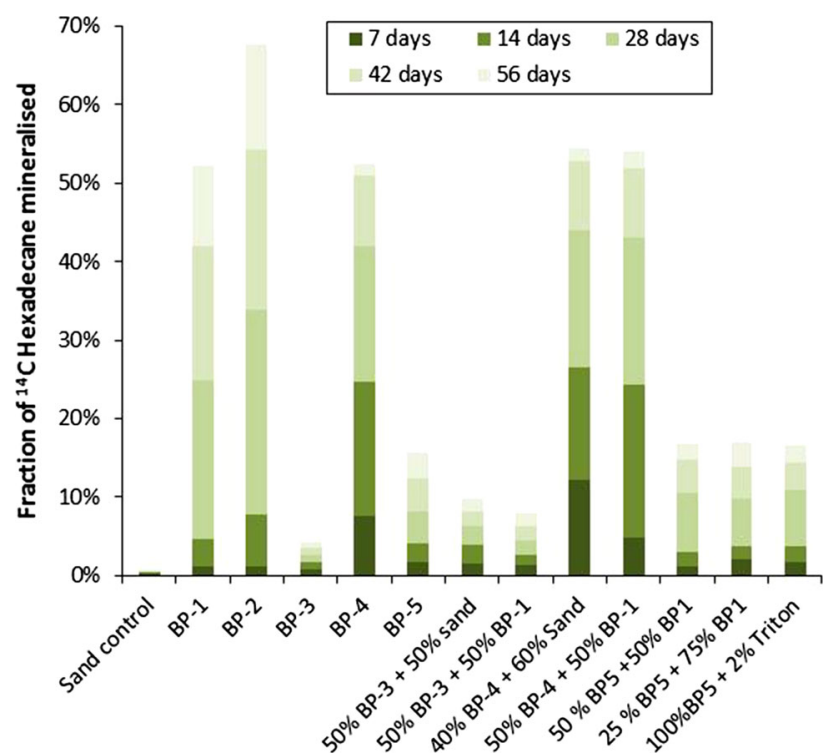

Fig. 5 Biodegradation of weathered hydrocarbons assessed through radiolabelled hexadecane mineralisation rates

between the HP- $\beta$-CD-extracted TPH concentration and the measured biodegradation observed in the microcosm studies. BP-3 and BP-5 were the two soils where the measured biodegradation was $<20 \%$ of original TPH concentrations. HP- $\beta$-CD extraction of soil BP-3 predicted that $50 \%$ of TPH in this soil would be biodegradable, but the results from the microcosm study showed that measured biodegradation was only $5 \%$. Poor mineralisation of ${ }^{14} \mathrm{C}_{16} \mathrm{H}_{34}$ might be the result of TPH toxicity due to the elevated TPH concentration $\left(123,757 \mathrm{mg} \mathrm{kg}^{-1}\right)$ in soil BP3. TPH inhibition of microbial activity has been reported previously (Batelle 2007). USEPA (1998) recommends that bioremediation through biopile technique should not be undertaken on soils with a TPH concentration $>50,000 \mathrm{mg} \mathrm{kg}^{-1}$. The apparent lack of mineralisation of ${ }^{14} \mathrm{C}_{16} \mathrm{H}_{34}$ in BP-3 might also be related to an operational artefact generated during the laboratory experiment. The artefact might have occurred during the localised addition of the ${ }^{14} \mathrm{C}_{16} \mathrm{H}_{34}$ compound as uniform distribution in soil with very high organic carbon was difficult. Having considered the high loads of hydrocarbons in BP-3, soil dilution (which is one of the recommended effective clean-up techniques) was carried out as a treatment option to reduce the hydrocarbon concentration. It increased mineralisation of ${ }^{14} \mathrm{C}_{16} \mathrm{H}_{34}$, by a further $6 \%$ when sand was used as a diluent, and by $3 \%$ when another contaminated soil (BP-1) was used as the diluent. However, dilution of BP-3 might not be helpful in achieving the clean-up target concentration, and apparently other treatment methods such as chemical oxidation need to be considered to reduce the hydrocarbon concentration in order to reach the clean-up threshold level.
Soil BP-5 showed a low mineralisation rate which might be due to the presence of the elevated fraction of $>\mathrm{C}_{29}$ hydrocarbons compared to the other soils studied. In BP-5, $>70 \%$ of the TPH present in the soil comprised the $>\mathrm{C}_{29}$ hydrocarbon fraction. The high molecular weight (MW) TPH fraction $\left(>\mathrm{C}_{29}\right)$ is strongly recalcitrant to microbial degradation due to low water solubility and low microbial bioavailability, thereby presenting great remediation challenge. As described earlier at the start of the results section in this paper, the high MW long-chain hydrocarbons are less soluble and more recalcitrant; hence, they are less available for uptake by the soil microbial community, and so less susceptible to microbial biodegradation (Alexander 2000). To overcome bioavailability constraint, surfactant supplementation was added to the soil BP-5. This procedure has been used for many years to deal with the bioavailability issue in remediation and has been reported extensively (Laha et al. 2009; Mulligan et al. 2001). Triton is the common surfactant used largely because of its ability to enhance desorption and solubilisation of petroleum hydrocarbons, thereby facilitating their assimilation by microorganisms (Yeung and $\mathrm{Gu}$ 2011). In this study, Triton $\mathrm{X}-100$ was added at $2 \%(\mathrm{v} / \mathrm{w})$, which did not result in marked improvement in the rate of hydrocarbon mineralisation. The high organic matter content of this soil (7.64\%) might be an inhibiting factor. Soil clay and organic matter are key factors related to the sorption of surfactants (Zhang et al. 2009). Yeh and Lin (2003) found a strong correlation between the sorption rate of Triton X-100 and the SOM content. Their study indicated that the rates of Triton X-100 sorption increased threefold when the $\mathrm{SOM}$ was increased from 5 to $25 \mathrm{~g} \mathrm{~kg}^{-1}$. Furthermore, in addition to reducing micelle formation, surfactant sorption also increases soil organic carbon content with implications on the partitioning behaviour of target hydrophobic organic compounds. Hence, the sorption of Triton in soil could be the reason for suboptimal improvement in the mineralisation rate of TPH in the BP-5. Although surfactant-enhanced remediation has been put forward as a promising technology for the rapid removal of hydrophobic organic compounds from contaminated soils, Triton supplementation was not advantageous in this study. Some other alternative remediation technique is required for BP-5 soils also as that of BP-3 soil.

\section{Bacterial diversity in the microcosm soils during bioremediation}

Microbial diversity analysis, through any reliable monitoring of biodegradation activities, is required to define the efficiency of the bioremediation process. A tool is required that can link physicochemical conditions of a site undergoing remediation with the dynamic characteristics of 
the contaminant-degrading microbial communities (resilience, stability, etc.) (Stenuit et al. 2008). Currently, 'high-throughput' techniques are increasingly being incorporated into the standard protocol of pilot scale and field studies of bioremediation. Therefore, in this treatability study, bacterial community analyses were conducted using 454 pyrosequencing from samples collected on days 0,7 , 14, 28 and 56, representing stages of the biodegradation phases (Fig. 6). The predominant phylum was Proteobacteria $(45-84 \%)$ in all samples prior to and after the bioremediation. The contribution of Alpha- or Gammaproteobacteria varied in the contaminated soils but Actinobacteria, Acidobacteria and Chloroflexi were the other dominant phyla represented. Proteobacteria, Firmicutes, Actinobacteria and Bacteriodetes have been previously identified as hydrocarbon-degrading organisms (Beazley et al. 2012; Bell et al. 2011; Liu and Liu 2013; Militon et al. 2010). Gemmatimonadetes, Bacteroidetes, Nitrospira, Firmicutes, Planctomycetes, Verrumicrobia, TM7, BRC1 and Cynobacteria comprised minor communities in the soil samples analysed.

The relative distribution of the Proteobacteria varied depending on the level of site contamination: high in the low-level TPH (1000 mg kg$\left.{ }^{-1}\right)$ contaminated soils and less so in high-level contamination $\left(123,579 \mathrm{mg} \mathrm{kg}^{-1}\right)$ at the start of the experiment. However, the trend changed during the remediation of the highly contaminated soil; Proteobacterial abundance increased. The Proteobacteria encompass an enormous range of bacteria with different morphological, physiological and metabolic diversity (Greer et al. 2010). Alpha- and Gammaproteobacteria were found in significant proportions in all the soils except BP-5 in which the Gamma-group is dominant. The family Rhizobiaceae represented the majority of the Alpha-group, and Pseudomonadaceae and Xanthomonadaceae dominated the Gamma-group at the start of the experiment in soils BP-1 and BP-2. These groups might have contributed to significant TPH removal in these two soils since they have been shown to possess hydrocarbon-degradation ability (Beazley et al. 2012). Gammaproteobacteria dominated the Alpha-group at the later part of the remediation, and the Alcanivoraceae became dominant in the biopile-treated soils BP-1 and BP-2. This major gamma shift occurred in the highly contaminated BP-3 soil. BP-5 soil differed greatly from the other soils, where the Gamma-group and also the other groups remained almost constant in their overall abundance throughout the treatment period. This indicates less change in the bacterial diversity, which supported the finding of a slow rate of TPH removal in this soil. Previous studies have often reported a shift in the balance of micro-organisms from Alpha- to the Gammaproteobacteria when soils are contaminated with hydrocarbons (Greer et al. 2010; Militon et al. 2010).
Altering the soil environment during the biopile bioremediation process by enhancing hydrocarbon solubility shifted the balance of the Proteobacteria group to be dominated by Gammaproteobacteria.

The taxonomic distribution of the families representing the Alpha- and Gamma-groups differed in the highly contaminated soil BP-3 where Azotobacteraceae and Sinobacteracae are the dominant members of the Alpha- and Gamma-groups, respectively. These two families have also been demonstrated to be hydrocarbon degraders by $\mathrm{Xu}$ et al. (2014). However, the abundance of Pseudomonads which is believed to be a major factor in determining the rate of bioremediation (Bell et al. 2011) was less in the BP3 , which might be a reason for the slow rate of TPH removal in this soil. Even with the presence of Pseudomon$a d s$ in large numbers in the contaminated soil BP-5, TPH removal was not significant, and also the overall change in the bacterial diversity was not pronounced in this soil as compared to the others, as it had a high proportion of recalcitrant hydrocarbons ( $70 \%$ of $>\mathrm{C}_{29}$ high MW TPH compounds). Soil BP-4 showed variation in the overall microbial diversity having a greater diversity of phyla than the other treated soils. Nitrospirae, NKB19, SBR 1093 and Elusimicrobia are some of the phyla represented in this soil, so showing a taxonomic distribution similar to that of a fertile agricultural soil which is supported by high diversity index at both the start and the end of the experiment (Table 4).

The Shannon diversity index was determined from the pyrosequencing data for all the soils treated through biopile in the microcosm experiment (Table 4). Soil BP-4 was observed to have high bacterial diversity and the index increased from 3.59 to 3.70 in 7 days after treatment, recording a more rapid change than for the other soils. Soils BP-1 and BP-2 also increased in the bacterial diversity but the increase was significant only after 14 days of treatment. The highly contaminated BP-3 soil had the lowest bacterial diversity at the start of the experiment. However, during the biopile treatment, there was an increase in the diversity up to 28 days and then a marked decrease. BP-5 showed a decreasing trend in the diversity and confirmed that the bacterial abundance had been less significantly changed. This indicates that the bacterial populations, which had presumably adapted to the presence of the contaminant (over years prior to the start of this study), were very stable and not affected by perturbations related to any amendments. An overall reduction in TPH levels together with a substantial shift in microbial populations occurred in all the soils studied with the exception of soil BP-5. Makadia et al. (2011) also reported that rapid changes in TPH of previously contaminated soils but that these may not always be accompanied by changes in the microbial community. 
Fig. 6 Pyrosequencing

bacterial diversity dynamics during biopile treatment of weathered petroleum hydrocarbons. $y$-axis (primary) represents non-Proteobacterial fractional abundance, and secondary $y$-axis represents Proteobacterial abundance
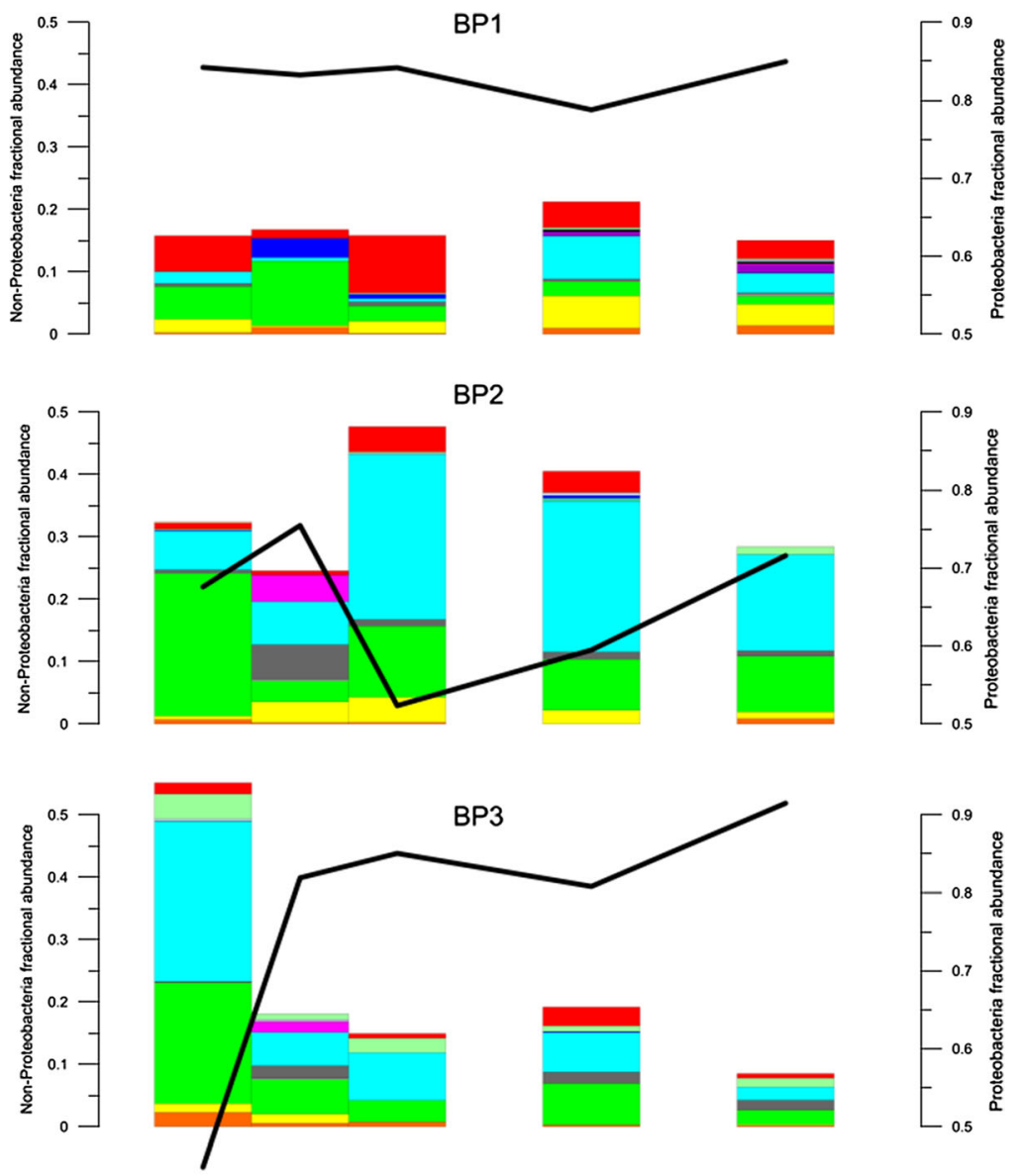

BP3
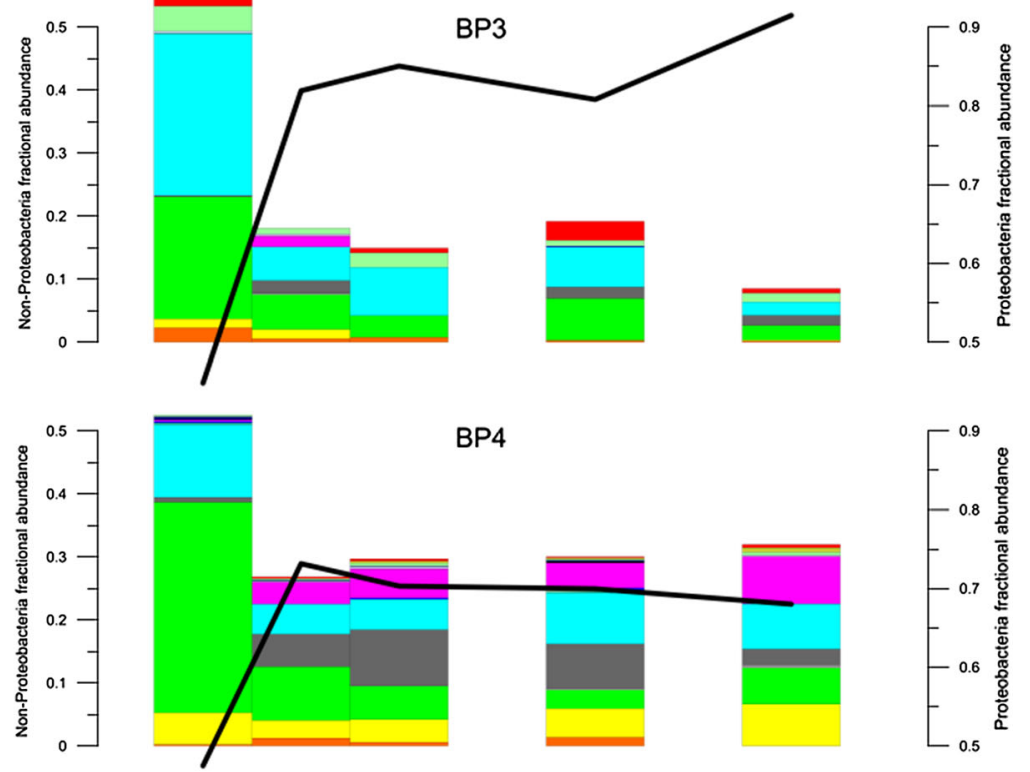

BP4
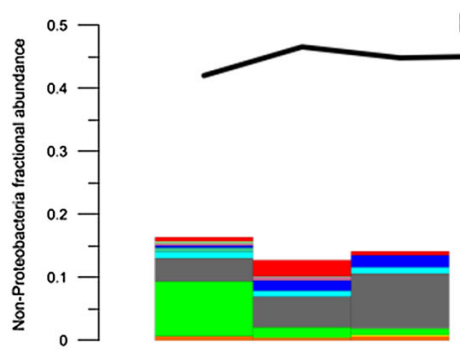

BP5
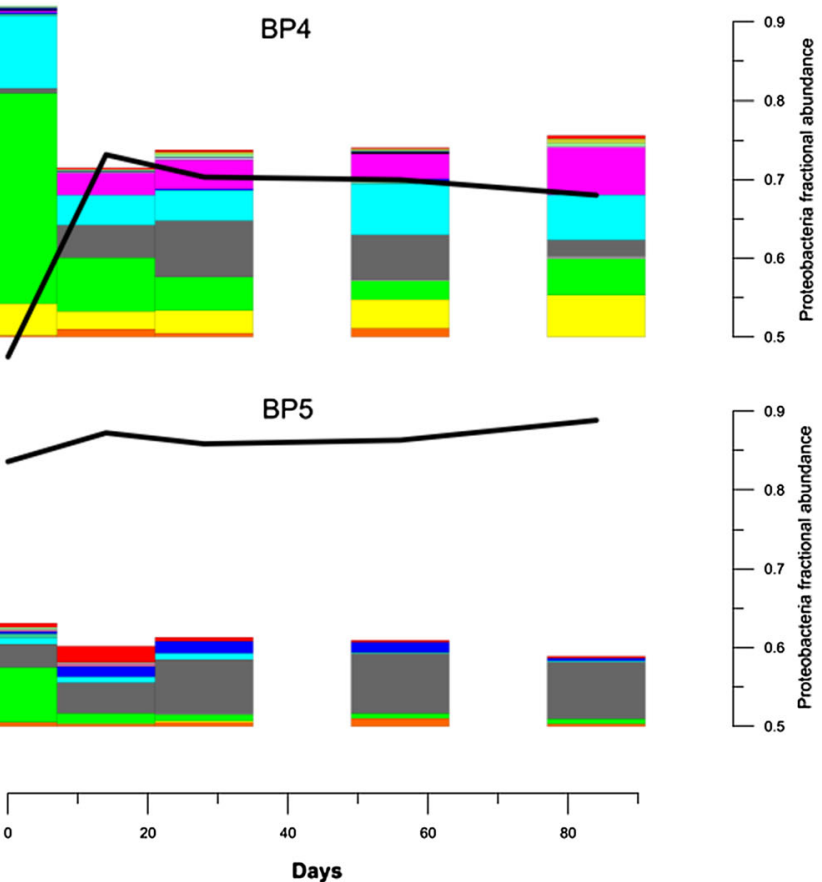

\begin{tabular}{|l|l|l|l|l|}
\hline Other & Chloroflexi & NKB19 & Proteobacteria & Nitrospirae \\
Acidobacteria & Firmicutes & Planctomycetes & Thermi & Elusimicrobia \\
Actinobacteria & GN02 & TM7 & WPS-2 & SBR1093 \\
BRC1 & Gemmatimonadete & Verrucomicrobia & Cyanobacteria & Synergistetes \\
Bacteroidetes & & & & \\
\end{tabular}


Table 4 Shannon-Weaver Index $\left(H^{\prime}\right)$ assessment of bacterial community diversity in the biopile microcosm

\begin{tabular}{llllll}
\hline Soil code & \multicolumn{5}{l}{ Days of sampling in the microcosm study } \\
\cline { 2 - 6 } & 0 & 7 & 14 & 28 & 56 \\
\hline BP-1 & 2.64 & 2.87 & 3.16 & 3.33 & 3.01 \\
BP-2 & 2.95 & 2.58 & 3.17 & 3.16 & 2.94 \\
BP-3 & 2.40 & 2.67 & 2.32 & 2.59 & 1.74 \\
BP-4 & 3.59 & 3.70 & 3.37 & 3.41 & 3.41 \\
BP-5 & 2.74 & 2.58 & 2.52 & 2.48 & 2.43 \\
\hline
\end{tabular}

\section{Conclusion}

This study conducted with petroleum hydrocarbon-contaminated soils collected from the arid region of Australia found that significant hydrocarbon biodegradation achieved in three of five soils (BP-1, BP-2 and BP-4) with optimised nutrient status and physical characteristics. Pyrosequencing data supported the TPH reduction with an increase in the bacterial diversity indices in these soils. Microbial diversity analysis in the other two soils BP-3 and BP-5 demonstrated the existence of hydrocarbon-degrading communities in these soils. However, bioremediation was not effective in these two soils, even after soil amendment and surfactant (Triton) addition, due to high hydrocarbon concentrations $\left(123,757 \mathrm{mg} \mathrm{kg}^{-1}\right)$ and recalcitrant hydrocarbons. Further modification of the biopile treatments was required for these soils. This study found that the extent of microbial degradation of TPH is dependent on the extent of contamination and solubility (bioavailability) of the TPH in the soil and the potential biodegradation endpoints can be estimated by utilising a prescreening (chemical) assay with the HPCD extraction. This study provides an overview of the major parameters that should be considered when evaluating the applicability of biopile remediation technology in the field.

Acknowledgments This research was funded and supported by BHP BIO Iron Ore, Western Australia through the Cooperative Research Centre for Contamination Assessment and Remediation of the Environment (CRC CARE), Adelaide, Australia.

\section{References}

Adetutu EM, Smith RJ, Weber J, Aleer S, Mitchell JG, Ball AS, Juhasz AL (2013) A polyphasic approach for assessing the suitability of bioremediation for the treatment of hydrocarbonimpacted soil. Sci Total Environ 450-451:51-58. doi:10.1016/j. scitotenv.2013.02.007

Admon S, Green M, Avnimelech Y (2001) Biodegradation kinetics of hydrocarbons in soil during land treatment of oily sludge. Biorernediation J 5:193-209
Alexander M (2000) Aging, bioavailability, and overestimation of risk from environmental pollutants. Environ Sci Technol 34:4259-4265

Atlas RM, Bartha R (eds) (1998) Fundamentals and Applications. Microbial ecology. Benjamin/Cummings Publishing Company, Inc, California, pp 523-530

Balba M, Al-Awadhi N, Al-Daher R (1998) Bioremediation of oilcontaminated soil: microbiological methods for feasibility assessment and field evaluation. J Microbiol Methods $32: 155-164$

Batelle (2007) Sediment toxicity of hydrocarbon fractions. Massachusetts Department of Environmental Protection Battelle, Duxbury, MA, USA

Beazley MJ et al (2012) Microbial community analysis of a coastal salt marsh affected by the Deepwater Horizon oil spill. PLoS ONE 7:e41305

Bell TH, Yergeau E, Martineau C, Juck D, Whyte LG, Greer CW (2011) Identification of nitrogen-incorporating bacteria in petroleum-contaminated arctic soils by using [15 N]DNA-based stable isotope probing and pyrosequencing. Appl Environ Microbiol 77:4163-4171. doi:10.1128/aem.00172-11

Beolchini F, Rocchetti L, Regoli F, Dell'Anno A (2010) Bioremediation of marine sediments contaminated by hydrocarbons: experimental analysis and kinetic modeling. J Hazard Mater 182:403-407. doi:10.1016/j.jhazmat.2010.06.047

Bernoth L, Firth I, McAllister P, Rhodes S (2000) Biotechnologies for remediation and pollution control in the mining industry. Miner Metallurg Proc 17:105-111

Bouchez Naitali M, Rakatozafy H, Marchal R, Leveau JY, Vandecasteele JP (1999) Diversity of bacterial strains degrading hexadecane in relation to the mode of substrate uptake. J Appl Microbiol 86:421-428. doi:10.1046/j.1365-2672.1999.00678.x

Brassington KJ et al (2007) Weathered hydrocarbon wastes: a risk management primer. Crit Rev Environ Sci Technol 37:199-232

Bull A (2011) Actinobacteria of the extremobiosphere. In: Horikoshi K (ed) Extremophiles handbook. Springer, Japan, pp 1203-1240. doi:10.1007/978-4-431-53898-1_58

Cerniglia CE, Sutherland JB (2010) Degradation of polycyclic aromatic hydrocarbons by fungi. In: Timmis K (ed) Handbook of hydrocarbon and lipid microbiology. Springer, Berlin, pp 2079-2110. doi:10.1007/978-3-540-77587-4_151

Chaillan F, Chaîneau CH, Point V, Saliot A, Oudot J (2006) Factors inhibiting bioremediation of soil contaminated with weathered oils and drill cuttings. Environ Pollut 144:255-265. doi:10.1016/ j.envpol.2005.12.016

CSIRO (2011) http://www.csiro.au/science/arid-land-sustainability

Ehlers LJ, Luthy RG (2003) Peer reviewed: contaminant bioavailability in soil and sediment. Environ Sci Technol 37:295A302A. doi:10.1021/es032524f

Ferguson SH, Franzmann PD, Revill AT, Snape I, Rayner JL (2003) The effects of nitrogen and water on mineralisation of hydrocarbons in diesel-contaminated terrestrial Antarctic soils. Cold Reg Sci Technol 37:197-212. doi:10.1016/S0165-232X(03)00041-7

Friedman SP (2005) Soil properties influencing apparent electrical conductivity: a review. Comput Electron Agric 46:45-70. doi:10.1016/j.compag.2004.11.001

Gardner WH (1986) Water content. In: Klute A (ed) Methods of soil analysis. Part 1. Physical and mineralogical methods, 2nd edn. Soil Science Society of America, Inc., Madison, WI

Gargouri B, Karray F, Mhiri N, Aloui F, Sayadi S (2013) Bioremediation of petroleum hydrocarbons-contaminated soil by bacterial consortium isolated from an industrial wastewater treatment plant. J Chem Technol Biotechnol. doi:10.1002/jctb.4188

Godoy-Faúndez A, Antizar-Ladislao B, Reyes-Bozo L, Camaño A, Sáez-Navarrete C (2008) Bioremediation of contaminated mixtures of desert mining soil and sawdust with fuel oil by aerated 
in-vessel composting in the Atacama region (Chile). J Hazard Mater 151:649-657. doi:10.1016/j.jhazmat.2007.06.038

Greer CW, Whyte LG, Niederberger TD (2010) Microbial communities in hydrocarbon-contaminated temperate, tropical, alpine, and polar soils. In: Timmis K (ed) Handbook of hydrocarbon and lipid microbiology. Springer, Berlin, pp 2313-2328. doi:10. 1007/978-3-540-77587-4_168

Griebler C, Lueders T (2009) Microbial biodiversity in groundwater ecosystems. Freshw Biol 54:649-677

Guerin TF (2002) Heavy equipment maintenance wastes and environmental management in the mining industry. J Environ Manage 66:185-199

Harmsen J, Naidu R (2013) Bioavailability as a tool in site management. J Hazard Mater. doi:10.1016/j.jhazmat.2012.12. 044

Hazen T, Tien A, Worsztynowicz A, Altman D, Ulfig K, Manko T (2003) Biopiles for remediation of petroleum-contaminated soils: a polish case study. In: Sasek V, Glaser JA, Baveye P (eds) The utilization of bioremediation to reduce soil contamination: problems and solutions. Springer, pp 229-246

Hazen TC et al (2010) Deep-sea oil plume enriches indigenous oildegrading bacteria. Science 330:204-208

Hua Z, Song R, Du G, Li H, Chen J (2007) Effects of EDTA and Tween60 on biodegradation of n-hexadecane with two strains of Pseudomonas aeruginosa. Biochem Eng J 36:66-71. doi:10. 1016/j.bej.2006.06.008

Huesemann MH, Hausmann TS, Fortman TJ (2002) Microbial factors rather than bioavailability limit the rate and extent of PAH biodegradation in aged crude oil contaminated model soils. Bioremediation J 6:321-336

Laha S, Tansel B, Ussawarujikulchai A (2009) Surfactant-soil interactions during surfactant-amended remediation of contaminated soils by hydrophobic organic compounds: a review. J Environ Manage 90:95-100

Liu Z, Liu J (2013) Evaluating bacterial community structures in oil collected from the sea surface and sediment in the northern Gulf of Mexico after the Deepwater Horizon oil spill. MicrobiologyOpen. doi:10.1002/mbo3.89

Makadia TH, Adetutu EM, Simons KL, Jardine D, Sheppard PJ, Ball AS (2011) Re-use of remediated soils for the bioremediation of waste oil sludge. J Environ Manage 92:866-871

Manz W, Amann R, Ludwig W, Vancanneyt M, Schleifer K-H (1996) Application of a suite of 16S rRNA-specific oligonucleotide probes designed to investigate bacteria of the phylum cytophaga-flavobacter-bacteroides in the natural environment. Microbiology 142:1097-1106. doi:10.1099/13500872-142-5-1097

Masakorala K, Yao J, Chandankere R, Liu H, Liu W, Cai M, Choi MM (2013) A combined approach of physicochemical and biological methods for the characterization of petroleum hydrocarbon-contaminated soil. Environ Sci Pollut Res 21(1). doi:10. $1007 / \mathrm{s} 11356-013-1923-3$

Mason OU et al (2012) Metagenome, metatranscriptome and singlecell sequencing reveal microbial response to Deepwater Horizon oil spill. ISME J 6:1715-1727

Militon C et al (2010) Bacterial community changes during bioremediation of aliphatic hydrocarbon-contaminated soil. FEMS Microbiol Ecol 74:669-681

Miller W, Miller D (1987) A micro pipette method for soil mechanical analysis. Commun Soil Sci Plant Anal 19:1-15

Mulligan C, Yong R, Gibbs B (2001) Surfactant-enhanced remediation of contaminated soil: a review. Eng Geol 60:371-380

Naidu R et al (2013) Towards bioavailability-based soil criteria: past, present and future perspectives. Environ Sci Pollut Res. doi:10. 1007/s11356-013-1617-x

Nikolopoulou M, Kalogerakis N (2009) Biostimulation strategies for fresh and chronically polluted marine environments with petroleum hydrocarbons. J Chem Technol Biotechnol 84:802-807. doi:10.1002/jctb.2182

Noordman WH, Wachter JHJ, de Boer GJ, Janssen DB (2002) The enhancement by surfactants of hexadecane degradation by Pseudomonas aeruginosa varies with substrate availability. J Biotechnol 94:195-212. doi:10.1016/S0168-1656(01)00405-9

Prince R (2010) Eukaryotic hydrocarbon degraders. In: Timmis KN (ed) Handbook of hydrocarbon and lipid microbiology. Springer, pp 2065-2078

Reid BJ, Stokes JD, Jones KC, Semple KT (2000) Nonexhaustive cyclodextrin-based extraction technique for the evaluation of PAH bioavailability. Environ Sci Technol 34:3174-3179

Rhykerd R, Crews B, McInnes K, Weaver R (1999) Impact of bulking agents, forced aeration, and tillage on remediation of oilcontaminated soil. Bioresour Technol 67:279-285

Riding MJ, Doick KJ, Martin FL, Jones KC, Semple KT (2013) Chemical measures of bioavailability/bioaccessibility of PAHs in soil: fundamentals to application. J Hazard Mater. doi:10. 1016/j.jhazmat.2013.03.033

Risdon GC, Pollard SJ, Brassington KJ, McEwan JN, Paton GI, Semple KT, Coulon F (2008) Development of an analytical procedure for weathered hydrocarbon contaminated soils within a UK risk-based framework. Anal Chem 80:7090-7096

Riser R (1998) Remediation of petroleum contaminated soils: biological, physical and chemical processes. Lewis Publisher, United States

Røberg S, Østerhus J, Landfald B (2011) Dynamics of bacterial community exposed to hydrocarbons and oleophilic fertilizer in high-Arctic intertidal beach. Polar Biol 34:1455-1465. doi:10. 1007/s00300-011-1003-4

Rocchetti L, Beolchini F, Ciani M, Dell'Anno A (2011) Improvement of bioremediation performance for the degradation of petroleum hydrocarbons in contaminated sediments. Appl Environ Soil Sci 2011:1-8. Art ID 319657. doi:10.1155/2011/319657

Ros M, Rodríguez I, García C, Hernández T (2010) Microbial communities involved in the bioremediation of an aged recalcitrant hydrocarbon polluted soil by using organic amendments. Bioresour Technol 101:6916-6923. doi:10.1016/j.biortech.2010. 03.126

Sanscartier D, Reimer K, Koch I, Laing T, Zeeb B (2009) An investigation of the ability of a 14C-labeled hydrocarbon mineralization test to predict bioremediation of soils contaminated with petroleum hydrocarbons. Bioremediation J 13:92-101

Saul DJ, Aislabie JM, Brown CE, Harris L, Foght JM (2005) Hydrocarbon contamination changes the bacterial diversity of soil from around Scott Base, Antarctica. FEMS Microbiol Ecol 53:141-155. doi:10.1016/j.femsec.2004.11.007

Semple KT, Morriss A, Paton G (2003) Bioavailability of hydrophobic organic contaminants in soils: fundamental concepts and techniques for analysis. Eur J Soil Sci 54:809-818

Semple KT, Doick KJ, Jones KC, Burauel P, Craven A, Harms H (2004) Peer reviewed: defining bioavailability and bioaccessibility of contaminated soil and sediment is complicated. Environ Sci Technol 38:228-231

Shastri S, Kamper S, Sonigra T, Hill T, Beales J (2012) Australia's mining thirst GTL solution

Stenuit B, Eyers L, Schuler L, Agathos SN, George I (2008) Emerging high-throughput approaches to analyze bioremediation of sites contaminated with hazardous and/or recalcitrant wastes. Biotechnol Adv 26:561-575. doi:10.1016/j.biotechadv.2008.07.004

Stroud JL, Paton GI, Semple KT (2008) Linking chemical extraction to microbial degradation of $14 \mathrm{C}$-hexadecane in soil. Environ Pollut 156:474-481. doi:10.1016/j.envpol.2008.01.018

Sutton NB et al (2013) Impact of long-term diesel contamination on soil microbial community structure. Appl Environ Microbiol 79:619-630. doi:10.1128/aem.02747-12 
Teng Y, Luo Y, Sun M, Liu Z, Li Z, Christie P (2010) Effect of bioaugmentation by Paracoccus sp. strain HPD-2 on the soil microbial community and removal of polycyclic aromatic hydrocarbons from an aged contaminated soil. Bioresour Technol 101:3437-3443. doi:10.1016/j.biortech.2009.12.088

Tibbett M, George SJ, Davie A, Barron A, Milton N, Greenwood PF (2011) Just add water and salt: the optimisation of petrogenic hydrocarbon biodegradation in soils from semi-arid barrow Island, Western Australia. Water Air Soil Pollut 216:513-525

USEPA (1998) Biopiles. Office of the Underground Storage Tank, US Environmental Protection Agency. Publication \# EPA 510-B-95007. http://www.epa.gov/swerust1/cat/biopiles.htm

USEPA (2004) Treatment technologies for site cleanup annual status report (11th edn). Rep. No. EPA-542-R-03-009, Office of Solid Waste and Emergency Response US EPA, Washington, DC. http://www.epa.gov/tio/download/remed/asr/12/asr12_full_ document.pdf

Voelkerding KV, Dames SA, Durtschi JD (2009) Next-generation sequencing: from basic research to diagnostics. Clin Chem 55:641-658

Volke-Sepúlveda TL, Gutiérrez-Rojas M, Favela-Torres E (2003) Biodegradation of hexadecane in liquid and solid-state fermentations by Aspergillus niger. Bioresour Technol 87:81-86. doi:10.1016/S0960-8524(02)00207-9

Walworth J, Woolard C, Braddock J, Reynolds C (1997) Enhancement and inhibition of soil petroleum biodegradation through the use of fertilizer nitrogen: an approach to determining optimum levels. Soil Sediment Contam 6:465-480

Wu J, Ju L-K (1998) Extracellular particles of polymeric material formed in $\mathrm{n}$-hexadecane fermentation by Pseudomonas aeruginosa. J Biotechnol 59:193-202. doi:10.1016/S01681656(97)00150-8

Xu J, Deng H, Huang T, Song S (2014) Enhanced biodegradation of crude oil in contaminated soil by inoculation of hydrocarbondegraders. Desalin Water Treat 52:5126-5135. doi:10.1080/ 19443994.2014.898433

Yeh C, Lin L-C (2003) Sorption and desorption kinetics of surfactants TX-100 and DPC on different fractions of soils. J Environ Sci Health A Tox Hazard Subst Environ Eng 38:1145

Yergeau E, Lawrence JR, Sanschagrin S, Waiser MJ, Korber DR, Greer CW (2012) Next-generation sequencing of microbial communities in the Athabasca River and its tributaries in relation to oil sands mining activities. Appl Environ Microbiol 78:7626-7637

Yeung AT, Gu Y-Y (2011) A review on techniques to enhance electrochemical remediation of contaminated soils. J Hazard Mater 195:11-29. doi:10.1016/j.jhazmat.2011.08.047

Zhang L, Xu Z (2008) Assessing bacterial diversity in soil. J Soils Sediments 8:379-388

Zhang G, Hu H, Sun W, Ni J (2009) Sorption of Triton X-100 on soil organic matter fractions: kinetics and isotherms. J Environ Sci 21:795-800. doi:10.1016/S1001-0742(08)62343-8

Zhang D-C, Mörtelmaier C, Margesin R (2012) Characterization of the bacterial archaeal diversity in hydrocarbon-contaminated soil. Sci Total Environ 421-422:184-196. doi:10.1016/j. scitotenv.2012.01.043 